\title{
Euclides da Cunha por vários ângulos
}

\section{Euclides da Cunha from different angles}

\author{
José Augusto Drummondi \\ i Professor, Centro de Desenvolvimento Sustentável/Universidade de Brasília. \\ Brasília - DF - Brasil \\ orcid.org/0000-0002-7349-0579 \\ jaldrummond@uol.com.lbr
}

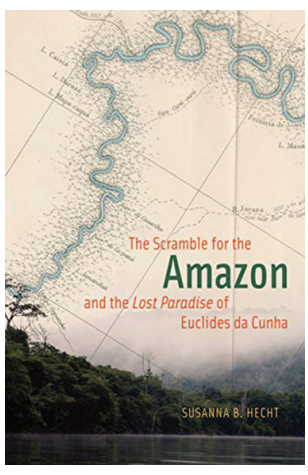

HECHT, Susanna. The scramble for the Amazon and the lost paradise of Euclides da Cunha. Chicago: The University of Chicago Press. 2014. $632 \mathrm{p}$.
Essa obra merece uma crítica inicial: trata-se de "vários livros" encadernados sob título e capa únicos. Além da descontinuidade entre seus componentes, a obra é um conjunto de livros enorme e heterogêneo, difícil de ler. Ainda assim, o conteúdo é valioso para quem se interesse por Euclides da Cunha e/ou pelo prolífico trabalho de Hecht sobre a Amazônia; no entanto, a obra não é para iniciantes.

Hecht é doutora em geografia pela University of California (Berkeley) e professora da University of California (Los Angeles). É veterana estudiosa do Brasil e da América Latina, sobre os quais publicou livros e artigos, especialmente a respeito de questões socioambientais, como The fate of the forest: developers, destroyers, and defenders of the Amazon (com Alexander Cockburn; edição atualizada em 2011) e Soy, globalization, and environmental politics in South America (com Gustavo L.T. Oliveira, 2017).

Hecht parece ter se cansado de escrever simultaneamente três ou quatro textos diferentes e resolveu unificá-los nessa obra. Isso resultou num produto de difícil definição: não é um livro de texto corrido, nem uma coletânea. Colocar vários textos inacabados sob um título único deu um fecho inadequado ao enorme trabalho da autora. O resultado exige que o leitor tente dar unidade ao descosturado texto final. Apesar disso, a qualidade da pesquisa, a forte capacidade analítica da autora, e a riqueza das fontes recomendam a leitura da obra aos interessados em Cunha e na região amazônica brasileira.

O título, apesar de longo, curiosamente não descreve o conteúdo da obra. Para fins da escrita desta resenha, identifico pelo menos "seis" livros distintos nessas 632 páginas: (1) Uma breve reapreciação do racismo "científico" de Cunha em Os sertões. O tema tem sido abordado por muitos autores, e é bem tratado por Hecht, mesmo que falte originalidade ao seu tratamento; 
(2) Uma fantasiosa "releitura" da rebelião de Canudos como precursora de múltiplas rebeliões "camponesas" no Nordeste brasileiro tragicamente pobre. Hecht sequer mostra que Os sertões contribui para "embasar" sua fantasia, o que torna essa segunda parte gratuita. Ela tampouco cita uma única outra rebelião camponesa ocorrida no Nordeste brasileiro nos últimos 100 anos. Essas duas primeiras partes da obra são parcialmente articuladas entre si, mas são escassamente articuladas com as quatro partes seguintes;

(3) Uma história um tanto árida (embora bem documentada) de (a) disputas diplomáticas entre Brasil e França sobre as atuais terras amapaenses e (b) disputas similares entre Brasil e Peru-Bolívia sobre as atuais terras acreanas. O mais intrigante desse terceiro "livro" é que, embora Cunha tenha atuado destacadamente na segunda disputa, o seu papel foi aparentemente "nulo" na primeira. A narrativa sobre o Amapá, embora faça parte das disputas internacionais sobre terras amazônicas mencionadas no título, é incongruente com o quarta, pois Cunha não aparece como protagonista nem como coadjuvante;

(4) Essa quarta parte inclui uma longa e detalhada narrativa sobre a viagem fluvial de Cunha pelo rio Purus, afluente da margem direita do rio Solimões. É o melhor e mais bem acabado "livro dentro do livro". Cunha viajou, junto com delegações brasileira e peruana, como representante máximo da diplomacia brasileira na disputa de terras amazônicas com o Peru. Hecht usa trechos eloquentes de cartas e anotações do diário de Cunha (incluindo cartas entre Cunha e o barão do Rio Branco), em que defende a soberania do Brasil sobre o território em disputa com base em argumentos altissonantes, mas chauvinistas e etnocêntricos (pouco ou nada criticados por Hecht, aliás);

(5) A quinta parte se liga tenuemente à quarta: Hecht reconstrói - e adere a - uma argumentação absurda de Cunha sobre o seringueiro como o herói social e político da consolidação da nacionalidade brasileira na Amazônia. Hecht se baseia em argumentos facciosos de Cunha, que em outros textos considera o seringueiro um trabalhador desterritorializado, explorado, inerme - ou seja, fraco candidato a herói da nacionalidade;

(6) Por último, fechando a obra, há um relato dramático dos últimos dias de Cunha. É uma narrativa estritamente biográfica, quase uma peça teatral trágica sobre a fragmentação de uma família. O relato íntimo da espiral declinante e dark de Cunha focaliza um homem infeliz e amargo, às voltas com a "infidelidade" da esposa que ele praticamente abandonou. Cunha mergulhou num deathwish e Dilermando de Assis executou seu desejo. Hecht nem tenta "costurar" esse sexto livro com o restante da sua obra ou com a obra de Cunha. É o mais "desgarrado" dos seis livros, embora seja bem construído como um fecho biográfico/dramático.

É impressionante a rica massa de livros analíticos e documentais, artigos e materiais primários usados e citados por Hecht, incluindo correspondências de Cunha aparentemente não usadas antes por outros estudiosos. A autora se deu ao trabalho de traduzir para o inglês longos trechos das cartas e anotações de diário de Cunha. Ela focaliza fundamentadamente muitas questões relevantes da ocupação europeia e brasileira da Amazônia, mas se permite interpretações embasadas apenas em suas preferências políticas.

A longa parte "biográfica" sobre o drama familiar e a morte de Cunha tem narrativa e temática que não "colam" com as quase quinhentas páginas anteriores e nada acrescentam ao Cunha "homem público", escritor, "intérprete" do Brasil. Além disso, Hecht tenta - e 
não convence - promover Ana de Assis (esposa de Cunha) como precursora da afirmação feminista no Brasil, uma aguerrida Anna Karenina dos trópicos.

É quase ridículo o contraste artificioso que Cunha faz na parte (5) entre os "caucheiros" peruanos e os seringueiros brasileiros. Sem críticas de Hecht, Cunha argumenta que os "caucheiros" seriam "predadores" de árvores chamadas caucho (nome popular; Castillo aulei), das quais tiravam látex e por isso seriam incapazes de construir instituições. No caso dos seringueiros brasileiros, Cunha os entroniza "patrioticamente" como construtores da nacionalidade brasileira, ou nation builders, nas plagas amazônicas, pelo mero fato de serem "sedentários". A alegada virtude "cívica" dos seringueiros residiria no fato de eles não derrubarem as seringueiras (Hevea brasiliensis) para retirar o látex. A própria Hecht, no entanto, descreve os seringueiros como trabalhadores criminosamente transplantados, mal adaptados e profundamente espoliados, ou seja, mal preparados para serem nation builders, e mesmo atores "ecologicamente adaptados" à floresta tropical.

Se Hecht publicou esse livro como "obra de maturidade", a sua opção foi lamentável. O escrito se baseia em muitos anos de leituras e pesquisa e contém vários textos independentes que ficaram "escondidos" pela falta de tempo, ou de vontade, da autora para os construir separadamente.

\section{REFERÊNCIAS}

HECHT, Susanna; OLIVEIRA, Gustavo L.T. (Ed.) Soy, globalization, and environmental politics in South America. London: Routledge. 2017.

HECHT, Susanna.

The scramble for the Amazon and the lost paradise of Euclides da Cunha. Chicago: The University of Chicago Press. 2014.
HECHT, Susanna; COCKBURN, Alexander (Ed.). The fate of the forest: developers, destroyers, and defenders of the Amazon. Chicago: The University of Chicago Press. Updated version. 2011. 